intakes were $14.2(\mathrm{n}=10)$ or $10.4(\mathrm{n}=10)$ Mcal per day, but daily supply of protein and amino acids was similar for all sows. Results were used to estimate maintenance requirements (MEm) and efficiency of $\mathrm{ME}$ utilization. During pregnancy, $\mathrm{MEm}$ averaged $100 \mathrm{kcal} \mathrm{ME} \mathrm{per} \mathrm{kg}$ metabolic weight $\left(\mathrm{kg}^{0.75}\right)$ and the efficiency of $\mathrm{ME}$ utilization for energy deposition was $76.6 \%$. Efficiencies of ME utilization for deposition of energy in uterine and maternal tissues were 48 and $85 \%$, respectively. During lactation, MEm was $109 \mathrm{kcal} \mathrm{ME} \mathrm{per} \mathrm{kg}^{0.75}$ and efficiency of utilization of $\mathrm{ME}$ and of energy of body reserves (mainly fat) for milk synthesis were 72 and 85 to $88 \%$, respectively. ME given during pregnancy for body reserve storage was used for milk synthesis with a 67 to $71 \%$ overall efficiency. These values are close to the efficiency of utilization of $\mathrm{ME}$ supplied during lactation for milk production $(72 \%)$. The interest of these results for prediction of energy requirements of sows by a factorial approach is discussed.

\title{
Weight gain partition in the pregnant sow : prediction by energy and protein intakes
}

\section{J.Y. DOURMAD}

INRA, Station de Recherches Porcines, Saint-Gilles, 35590 L'Hermitage (France)

A simulation model was used to predict weight gain partition in the pregnant sow according to energy and protein intakes. It is based on recent information concerning energy metabolism in the pregnant sow and on a comprehensive analysis of the main factors affecting nitrogen retention.

The model was validated using numerous literature data concerning the influence of feeding on weight variation during pregnancy. It allows a good prediction of total and net pregnancy weight gain ( $R=0.85$ and 0.83 , respectively) and gives the partition of that gain.

The different simulations emphasized the risk of establishing the feed requirements of the pregnant sow only on a weight gain basis without taking into account the effects on body composition. The development of this model also showed the lack of information about some of the factors affecting nitrogen deposition and about the effect of housing conditions.

\section{Effects of feeding wheat, maize or barley-based diets during pregnancy on reproductive performance of sows}

\author{
M. ETIENNE
}

INRA, Station de Recherches Porcines, Saint-Gilles, 35590 L'Hermitage

An experiment was carried out in 96 Large White sows to study the effects of pregnancy diets based on cereals on reproductive performance. Females were distributed into 4 groups and fed the same diet during the first two pregnancies. In the control group, animals were fed a diet including $86 \%$ barley and $10 \%$ soybean meal. In the other groups, diets contained $96 \%$ barley, wheat or maize without supplementary protein. Females ingested about $7 \mathrm{Mcal} \mathrm{DE} /$ day during pregnancy. The control diet was fed in restricted amounts during the three-week lactation period $(5 \mathrm{~kg} /$ day during the first cycle and $5.2 \mathrm{~kg} /$ day during the second one).

Weight changes of sows were related to the pregnancy diet. Total and net pregnancy weight gains were higher in the control group (mean of the two cycles : 58.3 and $41.4 \mathrm{~kg}$ for total and net gain, respectively), lower in the maize group $(39.4$ and $25.1 \mathrm{~kg}$ ) and intermediate in the barley (48 and $32.5 \mathrm{~kg}$ ) and wheat groups $(47.3$ and $31.7 \mathrm{~kg})$. Weight losses of the sows during lactation were all the more marked as weight gain was high during gestation $(-13.9,-6.0,-4.0$, and $-7.1 \mathrm{~kg}$ in the control, barley, wheat and maize groups, respectively). 